\title{
Tissue copper determinations by neutron activation analysis
}

\author{
A. P. TODD, M. E. C. THORPE, AND V. M. ROSENOER \\ From the Departments of Physics, Medicine, and Pharmacology, The Royal Free Hospital, \\ London
}

SYNOPSIS A method is described for the handling of tissue samples for copper determination by neutron activation analysis. The results obtained for normal liver copper estimations compared favourably with results obtained by conventional methods.

Activation analysis is a useful technique for the estimation of trace quantities of metals in biological tissue (Bowen and Gibbons, 1963). Neutron bombardment of tissue causes the elements present to become radioactive and emit radiation by which they may be identified. Copper 64 with a good activation cross-section and a half-life of $12 \cdot 8$ hours is particularly suitable for this technique and Plantin (1961) has described a method for estimation in serum.

The statement has been made that 'simplification of existing methods would reduce the danger of contamination and increase in sensitivity would allow the use of smaller samples' (Sass-Kortsak, 1965). The present paper describes a simple method for the determination of liver copper concentration by activation analysis.

\section{METHOD}

Liver tissue was taken from normal rats, rats previously injected with copper, regenerated rat livers, and human cadavers. The livers were dissected with nitric-washed perspex tools in a dust-free perspex box using rubber gloves to eliminate contamination.

Liver pieces of 5-200 mg. were transferred to a weighed polythene pot and the exact wet weight determined. These were freeze dried for six hours and re-weighed. A standard of approximately $10 \mathrm{mg}$. of Specpure ${ }^{1} \mathrm{CuSO}_{4}$ was also transferred to a weighed polythene pot and the exact weight determined. The samples and standard were then activated in the reactor at A.E.R.E., Harwell, using a neutron flux of $10^{12} \mathrm{n} / \mathrm{cm} .{ }^{2} / \mathrm{sec}$. and an irradiation time of 13 hours. The reaction taking place with thermal neutrons was ${ }_{29}^{63} \mathrm{Cu}+{ }_{0}^{1} \mathrm{n}-{ }_{29}^{64} \mathrm{Cu}+\gamma$. The neutron flux was

'Supplied by Johnson Matthey \& Co. Ltd.

Received for publication 26 August 1966. tested for homogeneity by a series of $\mathrm{CuSO}_{4}$ standards of varying weights; the activity per gram fell within the accepted statistical limits. Within five hours of removal from the pile, the samples were returned and ready for processing.

Livers were transferred to Kjeldahl flasks together with several washings of the polythene pots with $24 \mathrm{~N} \mathrm{HNO}_{3}$. The $\mathrm{CuSO}_{4}$ standard was transferred with $24 \mathrm{~N} \mathrm{HNO}_{3}$ to a $250 \mathrm{ml}$. measuring flask and the volume adjusted with ion-free water. The liver samples and $0.5 \mathrm{ml}$. aliquots of the standard were wet ashed $\left(\mathrm{HNO}_{3} ; \mathrm{HClO}_{4}=9: 1\right)$ for two hours to dryness. When cool $10 \mathrm{ml}$. $2 \mathrm{M}$ acetate buffer $p \mathrm{H} 5 \cdot 3$ (Dawson, Elliott, Elliott, and Jones, 1959) was added to each digest, to a final $p H$ of $5 \cdot 3$.

Dowex A.1 columns were prepared during the digestion of the samples. Columns $(2 \mathrm{ml}$. polythene syringes) were arranged as in Figure 1. In each a glass wool plug was inserted and $1 \mathrm{ml}$. of Dowex A.1 resin added (Bio-rad analytical grade chelating resin, Chelex 100, 100-200 mesh, sodium form). The resin was prepared with two-bed volumes $3 \mathrm{~N} \mathrm{HC1}$, five-bed volumes ion-free water rinse, two-bed volumes $1 \mathrm{~N} \mathrm{NaOH}$, and five-bed volumes ionfree water rinse. The final $p \mathrm{H}$ was adjusted to $5 \cdot 3$ with $\mathrm{Na}$ acetate buffer.

Each digest was transferred to a prepared resin column. The columns were washed with $40 \mathrm{ml}$. $2 \mathrm{M} \mathrm{NaCl}$ and then $20 \mathrm{ml}$. $2 \mathrm{M} \mathrm{MnCl}_{2}$. The columns were detached from their upper reservoirs, placed in a standard counting vial, and their radioactivity was measured. It should be noted that the heights of the resin columns must be kept within $1 \frac{1}{2} \mathrm{~cm}$. of the base of the $9 \mathrm{~cm}$.-deep well of the NaI(T1) crystal, and within 2 or $3 \mathrm{~mm}$. variation from sample to sample. This ensures that the positron 1.02 Mev. annihilation coincidence peak has a constant ratio to the 0.511 positron annihilation peak on each sample.

The samples were counted in a $\mathrm{NaI}(\mathrm{T} 1)$ well crystal on a Packard Auto-Gamma counter. The 0.511 Mev. positron annihilation photo peak and $1.02 \mathrm{Mev}$. positron annihilation coincidence photo peak were used for measuring the ${ }^{64} \mathrm{Cu}$ radioactivity. The weight of copper present in each sample was calculated after subtracting 


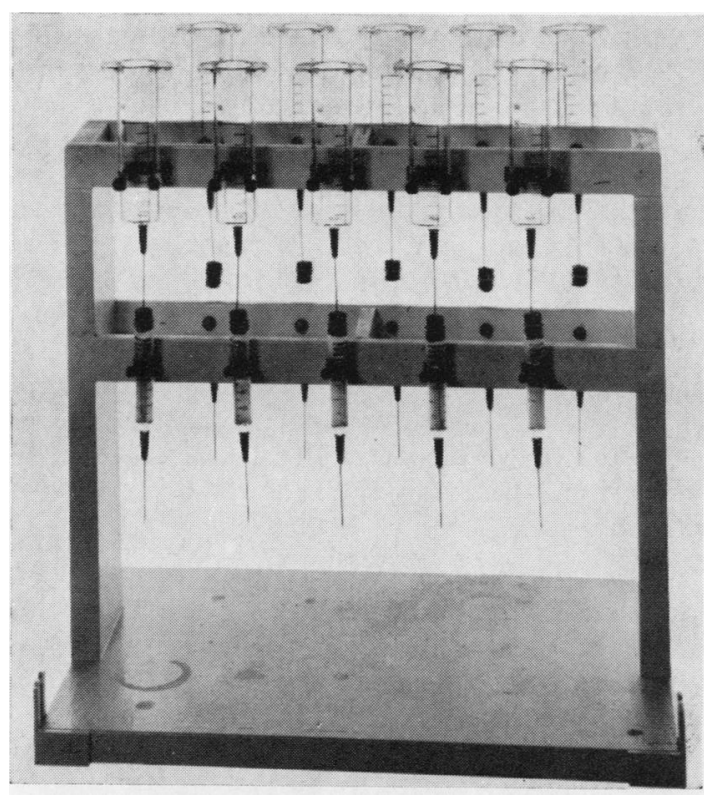

FIG. 1. Ten resin columns with attached reservoirs prepared for use.

the counts per minute due to the long lived impurity using the formula:

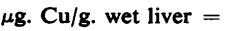

$\mu \mathrm{g}$. Cu standard $\times$ counts $/ \mathrm{min}$. of sample

Counts/min. of standard $\times$ wt. in $\mathrm{mg}$. of wet liver $\times 1,000$

The chemical purity of the samples was checked by spectral analysis using a 400 channel pulse analyser in conjunction with a flat $\mathrm{NaI}(\mathrm{T} 1)$ crystal. As a further check on the presence of possible contaminating elements, $\mathrm{Na}, \mathrm{K}, \mathrm{Mn}, \mathrm{Ca}, \mathrm{Ni}$, and $\mathrm{Zn}$ were irradiated and treated in the same way as the $\mathrm{Cu}$ standard and tissue samples. In addition samples had their radioactivity checked over a period of time to identify any other elements present on the column by half-life measurement.

\section{RESULTS}

Rat and human liver liver copper concentrations determined by this method are shown in Table I.

In a series of digested standards $98.9-101 \%$ was recovered on the columns and no ${ }^{64} \mathrm{Cu}$ was eluted in the washings.

Spectral analysis of the columns for both tissues and standards indicated peaks at $0.511 \mathrm{Mev}$. and $1.02 \mathrm{Mev}$. which were identifiable with ${ }^{64} \mathrm{Cu}$ (Fig. 2). The $1.02 \mathrm{Mev}$. peak was not seen on the flat $\mathrm{NaI}(\mathrm{Tl})$ crystal as it is the positron annihilation coincidence peak. This enabled the assessment of the nonpositron emitting impurities behind the peak to be estimated at less than $3 \%$ of the total peak counts at $1.02 \mathrm{Mev}$. The rest of the spectrum from $0.6 \mathrm{Mev}$. upwards did not exceed $1 \%$ of the $0.511 \mathrm{Mev}$. peak total counts. In particular the absence of significant peaks at 1.37 and $2.75 \mathrm{Mev}$. indicated that no ${ }^{24} \mathrm{Na}$ was present. Strict adherence to the correct $p \mathrm{H}$ was essential to ensure that all the copper was held on the column and all the sodium was eluted. If the $p H$ was less than 3 , the ${ }^{64} \mathrm{Cu}$ was lost from the column. If the $p \mathrm{H}$ was greater than 6.5 the ${ }^{24} \mathrm{Na}$ was retained on the column. ${ }^{24} \mathrm{Na},{ }^{47} \mathrm{Ca}$, and ${ }^{56} \mathrm{Mn}$ were completely removed from the column by washing with

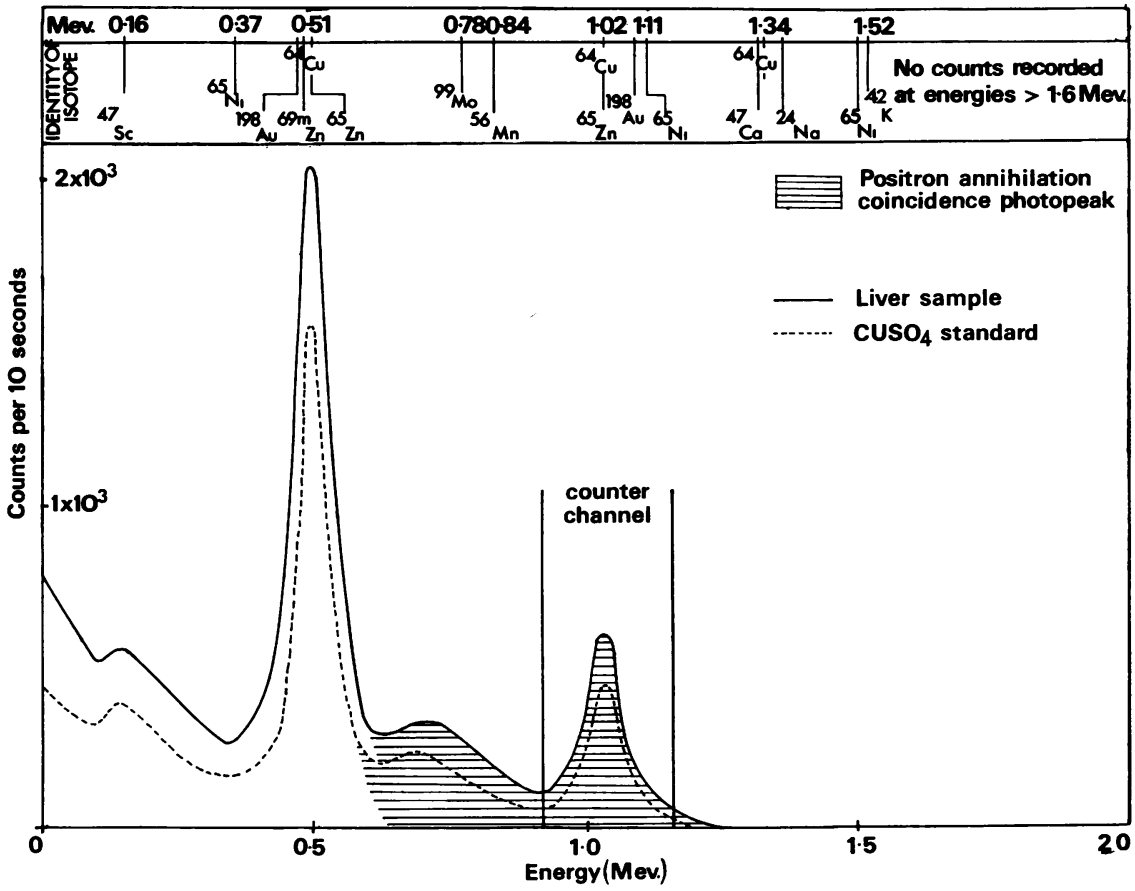

FIG. 2. Spectral analysis of the radioactivity of a typical liver sample and $\mathrm{CuSO}_{4}$ standard using a Packard autogamma counter. 
TABLE I

LIVER COPPER CONCENTRATIONS, MEASURED AT 1.02 MEV. PEAK, OF NORMAL RAT LIVER, REGENERATIVE RAT LIVER, COPPER-INTOXICATED RAT LIVER, AND NORMAL HUMAN NECROPSY LIVER

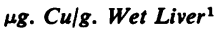

\begin{tabular}{|c|c|c|c|c|}
\hline \multicolumn{2}{|c|}{ Normal Rat Liver } & \multirow[b]{2}{*}{$\begin{array}{l}\text { Regenerative } \\
\text { Rat Liver }\end{array}$} & \multirow{2}{*}{$\begin{array}{l}\text { Copper- } \\
\text { intoxicated } \\
\text { Rat Liver }\end{array}$} & \multirow[b]{2}{*}{$\begin{array}{l}\text { Normal } \\
\text { Human Liver }\end{array}$} \\
\hline $\begin{array}{l}\text { Initial } \\
\text { Sample }\end{array}$ & $\begin{array}{l}\text { Duplicate } \\
\text { Sample }\end{array}$ & & & \\
\hline $\begin{array}{l}5 \cdot 1 \\
4 \cdot 45 \\
6.08 \\
5.06 \\
5 \cdot 7 \\
5 \cdot 95 \\
4 \cdot 1\end{array}$ & $5 \cdot 36$ & $\begin{array}{l}9.2 \\
8.0 \\
6.9\end{array}$ & $\begin{array}{l}75 \cdot 4 \\
68 \cdot 5 \\
52.5\end{array}$ & $\begin{array}{l}4 \cdot 7 \\
7.3 \\
5.4 \\
9.0 \\
7.9 \\
4.5 \\
7.5\end{array}$ \\
\hline
\end{tabular}

11 g. wet liver $=290 \pm 5 \mathrm{mg}$. dry liver (mean \pm standard error).

$\mathrm{NaCl}$ and $\mathrm{MnCl}_{2}$. The absence of ${ }^{24} \mathrm{Na}$ (as indicated previously) meant that Compton scattered radiation from this isotope did not obscure the 0.511 and 1.02 Mev. peaks of ${ }^{64} \mathrm{Cu}$.

${ }^{69} \mathrm{~m} \mathrm{Zn}$ and ${ }^{65} \mathrm{Zn}$ were partially removed from the column (approximately 50\%) with these washes. However, only negligible amounts of ${ }^{65} \mathrm{Zn}$ were manufactured in the 13-hour activation time (crosssection 0.22 barns, $\mathrm{O}^{t} \frac{1}{2} 245$ days). This was validated by less than $1 \%$ of the initial total counts being present in both the $0.511 \mathrm{Mev}$. and the $1.02 \mathrm{Mev}$. channels 10 days later (Fig. 3 ). The ${ }^{69} \mathrm{~m} \mathrm{Zn}$ has a 13.8

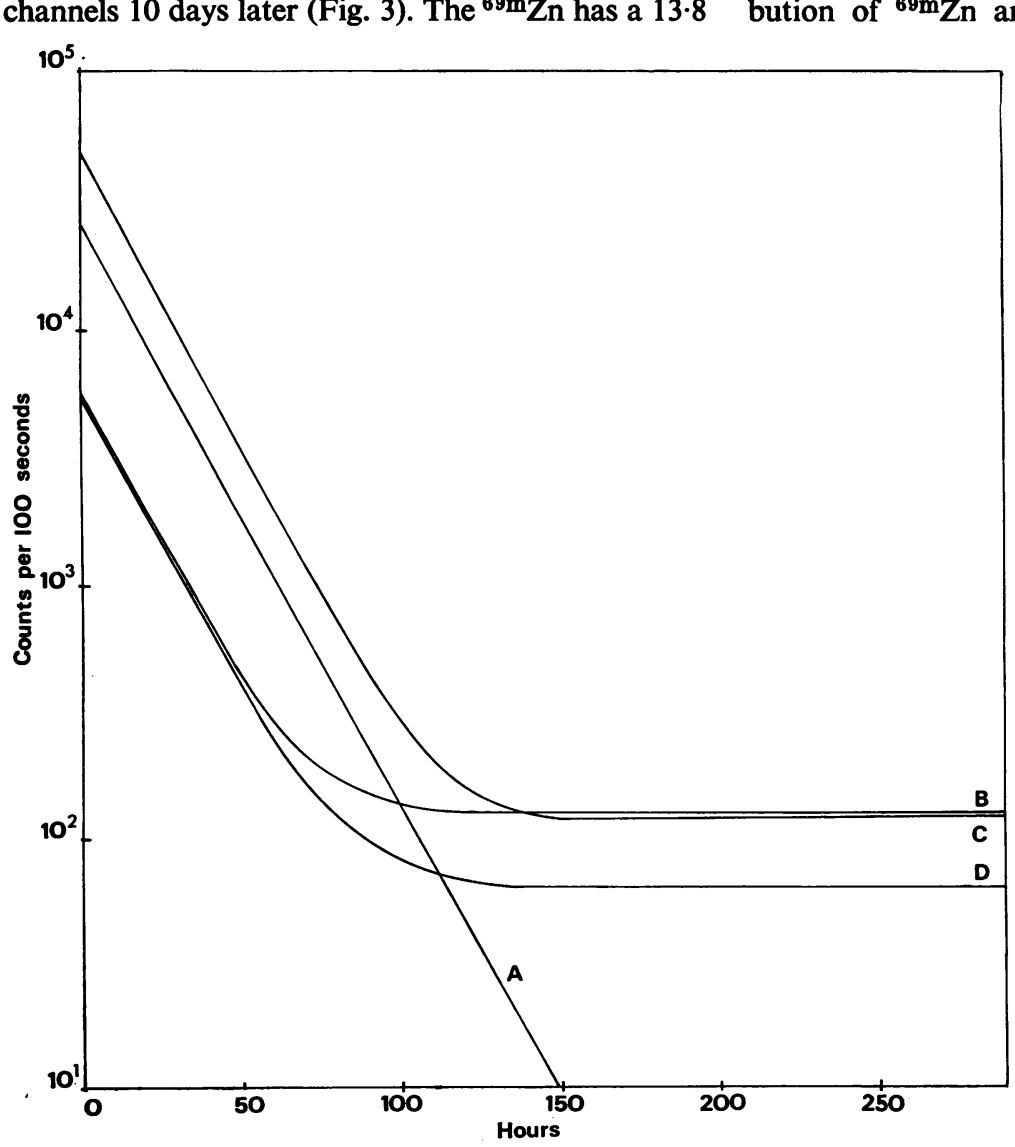

hour half-life but a low cross section for activation ( 0.018 barns as compared with 3 barns for copper). Therefore zinc would produce minimal counts as compared to an equivalent amount of copper. As a further check for the presence of abnormal quantities of ${ }^{69} \mathrm{Zn}$, spectral analysis would demonstrate a peak at $0.44 \mathrm{Mev}$. and the ratio of the total counts in the $0.511 \mathrm{Mev}$. channel, which would embrace the $0.44 \mathrm{Mev}$. peak, to the $1.02 \mathrm{Mev}$. channel counts, would exceed that of the standard ratio (approximately 3 depending on the electronic settings of pulse analysers). This would give a systematic overestimation of $\mathrm{Cu}$ as determined in the $0.511 \mathrm{Mev}$. channel compared with that in the $1.02 \mathrm{Mev}$. channel.

\section{DISCUSSION}

The method described separates $\mathrm{Cu}$ from $\mathrm{Ca}, \mathrm{Mn}$, and $\mathrm{Na}$ but is not satisfactory for the separation of ${ }^{69} \mathrm{~m} \mathrm{Zn}$ and ${ }^{65} \mathrm{Zn}$. However, it is possible to differentiate ${ }^{65} \mathrm{Zn}$ because of its longer half-life and ${ }^{69 \mathrm{~m}} \mathrm{Zn}$ because of the different ratio between the $0.511 \mathrm{Mev}$. and the $1.02 \mathrm{Mev}$. channels. In practice all samples are counted in both the $0.511 \mathrm{Mev}$. and $1.02 \mathrm{Mev}$. channels and any impurities in the 1.02 Mev. peak, except for positron emitters, are estimated by spectral analysis with the flat $\mathrm{NaI}(\mathrm{Tl})$ crystal and multichannel analyser. Similar analysis at the $0.511 \mathrm{Mev}$. photopeak was not able to show the exact contribution of ${ }^{69} \mathrm{~m} \mathrm{Zn}$ and the possible contribution of

FIG. 3. Decay of radioactivity of liver and $\mathrm{Cu}$ standard samples measured over 10 days. $A=$ $\mathrm{CuSO}_{4}$ standard; $\mathrm{B}=$ normal rat liver; $\mathrm{C}=\mathrm{Cu}$ loaded rat liver: $\boldsymbol{D}=$ human liver. 
other low energy contaminants, e.g. ${ }^{198} \mathrm{Au}$, and for this reason the $1.02 \mathrm{Mev}$. peak is preferable. However, to take into account the contribution of ${ }^{65} \mathrm{Zn}$ or any other long-lived positron emitter, counts should always be taken 10 days later.

With very small samples the $0.511 \mathrm{Mev}$. peak may be preferred because of the higher count rate. At this setting it is possible to estimate impurities, e.g., ${ }^{198} \mathrm{Au}$, by following the decay of the sample radioactivity closely for at least 10 days, together with spectral analysis.

The present method involves minimal handling of tissue before irradiation and has the advantage over a conventional chemical method in that following irradiation any further copper contamination is no longer important. It is a comparatively simple technique requiring simple chemical methods and the use of a single column which can be assayed intact without elution of copper. The method has the advantage of rapidity making it possible to estimate a unit of 10 samples within five hours of delivery.

The results obtained for normal rat estimations of copper compare favourably with results obtained by conventional methods, e.g., $22 \cdot 1 \mu \mathrm{g}$. $\mathrm{Cu} / \mathrm{g}$. dry liver by polarography (Everett, Day, and Bergel, 1964), $5.44 \pm 0.42^{\mu \mathrm{g}} / \mathrm{Cu} / \mathrm{g}$. wet liver by spectrophotometry (Allen and Schnieden, 1962). The results obtained for the normal human liver estimations of copper also compare favourably with results obtained by conventional methods, e.g., $5 \cdot 1 \mu \mathrm{g}$./g. wet liver by spectrophotometry (Cartwright and Wintrobe, 1964). The very small pieces of tissue which can be analysed for copper content by this method make it suitable for samples available from percutaneous liver biopsies.

It should be noted that coincidence counting, using suitably sensitive equipment, would be the method of choice for assessing the radioactivity; this would count positron emitting isotopes only.

We should like to thank Professor S. Sherlock and Mr. H. S. Williams for making this investigation possible. We are also indebted to Dr. L. O. Plantin for his advice.

We should also like to thank the M.R.C. unit at Hammersmith Hospital and the Middlesex Hospital for the use of their multichannel analysers, and Mr. A. C. Lillie for making the tools and apparatus.

This work was carried out during the tenure by one of us (M.E.C.T.) of a travel grant from The Royal Australasian College of Physicians.

\section{REFERENCES}

Allen, W. D., and Schnieden, H. (1962). Proc. Soc. exp. Biol. (N.Y.), $110,346$.

Bowen, H. J. M., and Gibbons, D. (1963). Radioactivation Analysis. Oxford University Press, London.

Cartwright, G. E., and Wintrobe, M. M. (1964). Amer. J. clin. Nutr., $14,224$.

Dawson, R. M. C., Elliott, D. C., Elliott, W. H., and Jones, K. M. (1959). Data for Biochemical Research. p. 197. Oxford University Press, London.

Everett, J. L., Day, C. L., and Bergel, F. (1964). J. Pharm. Pharmacol., $16,85$.

Plantin, L. O. (1961). Proc. 1961 int. Confr. on Modern Trends in Activation Analysis, p. 141.

Sass-Kortsak, A. (1965). Advanc. clin. Chem., 8, 1. 